\title{
A Review of Existing Literature on Sustainability, Mission Drift and Loan Defaults
}

\author{
Dr.Kashif Beg \\ Assistant Professor, M.A.J.U., Rampur, India
}

\begin{abstract}
As the abundance of research work has been done in the field of Microfinance in the last two decades. This research work deals with the issue of factors affecting operational self-sufficiency, financial self-sufficiency and loan repayment performance and the trade-off between financial performance and outreach to poor and women clients. The section one deals with prior research work on factors affecting the sustainability of MFIs. Section two reviews prior research works on Mission drift i.e. trade-off between sustainability and outreach. Finally, section three deals with the factors affecting loan repayment performance.
\end{abstract}

\section{SUSTAINABILITY}

De Crombruggheet. al. (2008) used regression to identify the factors affecting financial sustainability of microfinance institution in India. Cost average by revenue, repayment of loans and cost control are the three indicators used to study different aspects of sustainability. The study is based on database datasets of 42MFIs for the year 2003 provided by SADHAN (A nonprofit microfinance coordination and analysis organization). The result suggests that challenge of cost covering on small and partly unsecured loan can be met without increasing the size of the loan. MFIs can achieve financial sustainability without compromising with outreach to poor. The empirical result revealed most of the MFIs are unable to cover their cost.

Schafer and Fukasawa (2011) in their paper titled, "Factors determining operational self-sufficiency among Microfinance institutions" investigate the factors affecting the operationalself-sufficiency of MFIs. The empirical investigation is based on the data of 1,000 MFIs retrieved from MIX market for the year 2006 and 2008 scattered in different parts of the world. Their empirical findings by multiple regression analysis revealed that number of borrowers, write-off ratio were found to be important determinants of operational selfsufficiency. Moreover, there was no significant difference in 2006 before the worldwide financial crisis and in 2008.

Zerai\& Rani (2012) examined technical efficiency of Ethiopian microfinance institution (MFIs) by utilising data from 19 microfinance institution taken from mix market with the help of stochastic frontier analysis. The findings of the study revealed that average efficiency score of $71.72 \%$ of Ethiopian MFIs. Assets, operational sustainability, depth of outreach have significant impact on efficiency. The empirical findings confirm trade-off between efficiency \& outreach of Ethiopian MFIs.

Cull, Demirgüç-Kunt\& Morduch(2011) examines by using dataset of 245 microfinance Institution effect of prudential supervision on MFI profitably outreach to small-scale borrowers and women. Their finding suggests that profit oriented microfinance institution responds to supervision by maintaining profit rates \& but at the cost outreach to women \& poor client that are costly to reach .Their empirical finding shows that supervision has a negative effect on outreach because supervision is positively related with average loan balance while it is negatively related to the percentage of women borrowers.

Gutiérrez-Nieto, Serrano-Cinca\&Molinero(2009) in their paper discussed thedual performance of MFIs i.e. social \& financial performance. Out of data set of 450 institutions for the year 2003 from mix microfinance information exchange, only 89 MFIs were selected for which complete information was available. Data 
elopement analysis (DEA) was used to calculate the social \& financial efficiency of MFIs. Operating cost and assets gross loan portfolio used as inputs. Gross loan portfolio \& financial revenue are used as outputs for measuring financial efficiency. No. of active borrowers \& indicator of benefit to the poorest are used as output variable to calculate social efficiency. The result of financial efficiency and social efficiency was correlated with various financial ratios to withdraw the result \& interpretation. The findings of this paper suggest that except one, no MFIs are socially efficient but financially efficient MFIs exist. There is low positive relationship between the social\& financial efficiency of MFIs.

Tehulu (2013) used unbalanced panel data from 2004 to 2009 of 23 microfinance institutions in east Africa to identify the factors affecting financial sustainability. The study used binary probit\& ordinary probit regression models to identify the factors. The empirical result regression revealed that management efficiency \& portfolio at risk is negative \& significantly related with financial sustainability. Management inefficiency, portfolio at risk, loan intensity \& size are important factors of financial sustainability.

Rai (2012) in his research work "A comparative analysis of the financial performance of microfinance institutions of India and Bangladesh" analysed the financial performance of Indian MFIs and compared it MFIs of Bangladesh from different point of view by using various performance indicators \& Ratios. Mann-Whitney U test is used to compare the financial performance of India \& Bangladesh MFIs. Kruskal-Wallisone-way ANOVA is used to analyse age wise performance of Indian MFIs after categorising MFIs into young, mature \& old. This study covers the period of 2007-08.There is no significant difference between the means of Bangladesh \& Indian MFIs on operational self-sufficiency, yield on gross loan portfolio \& return on assets .NBFC MFIs are financially more viable \& outreach is high.

Masood \& Ahmad (2010) measured the technical efficiency of microfinance institution by applying the stochastic frontier approach of unbalanced panel data of 40 microfinance institutions withdrawn from mix market for the period 2005-08. The objective of the study is to benchmark the best practice MFIs by assigning ranks \& to determine the factors responsible for variation in efficiency level. The findings of the study revealed that efficiency level of microfinance institution is very low \& it is increasing during the study period \& there is no evidence of trade off. MFIs in the southern part of India are more efficient than other MFIs. Moreover, unregulated MFIs are more efficient than regulated MFIs.

Gutierrez-Nieto, Serrano-Cinca\&Molinero (2007) employed data envelopment analysis (DEA) approach to efficiency to prove that ratio analysis does not capture DEA efficiency. This study highlights an important aspect that, "how DEA model is specified" i.e. which input \& output variables should be chosen. A methodological approach based on multivariate analyses is applied in order to choose appropriate model specifications \& to produce ranking of MFIs in terms of efficiency. The finding of the study is based on data obtained data of 30 MFIs from micro rate web page from the year 2003. The selection of inputs \& outputs indicators is based on Yaron's (1994) outreach \& sustainability framework. The study reveals that level of MFIs depends on the particular model. That model is also relevant for efficiency assessment .Their suggestion to the policy makers, analyst, rating agency \& users to incorporate measures of efficiency based on DEA.

Martinez-Gonzalez (2008) examined the technical efficiency of microfinance institution by using DEA \& also identify differences in efficiency with the help of Tobit regression average loan size, proportion of assets used as performing portfolio, scale of operation, ratio of payroll to expenses, age, structure of the board \& for profit status of MFIs are the indicators used to determine differences in efficiency. The empirical evidence shows the trade-off between sustainability \& outreach in Mexican MFIs. Moreover, this study provides an idea how to use tools to analyse the relative technical efficiency of MFIs.

Hassan \& Sanchez (2009) investigates about the technical \& scale efficiency of MFIs by using Data elopement analysis. The data of 215 MFIs was taken from MIX market (A CGAP data base of MFIs around the globe). These MFIs are scattered in the region of Latin America, Middle East \& North Africa \& South Asia. The efficiency of MFIs is analysed following both production approach \& intermediation approach. The inputs 
indicators for the intermediation approach are operating expenses, total financial expenses \& labour. The indicators used as output in intermediation approach are gross loan portfolio, total funds \& financial revenues. On the other hand, operating expenses \& labour are used as input in production approach \& Numbers of the active borrower is as the only input. The empirical findings of the study depict that technical efficiency is higher for formal MFIs. South Asian MFIs have higher efficiencies in comparison to Latin America \&Middle East \& north African MFIs. The efficiencies are of purely technical nature i.e. MFIs are wasting their resources \& not producing enough outputs.

Nawaz, Hudon\&Basharat(2011) in his research paper analyse the efficiency of microfinance institutions in Pakistan by taking data from Pakistan Micro Finance network for the year 2003 \& 2007. The non-parametric mathematical programming approach (DEA) Data envelopment analysis has been used to analyse the efficiency of MFIs in delivering credit to poor section. The findings of DEA depicts that out of 12 there is three microfinance institution for the year 2003 FMFBL, SUNGI\& TARAQEE are on efficient frontier and both constant return to scale \& variable return to scale assumptions. In the year 2009 out of 19 only four i.e. POMFB, RMFB, NMFB \& TF are efficient under both assumptions. Inefficient MFIs must enhance the managerial skills \& improve technology.

Hudon\& Traca (2011) in their paper study the impact of subsidy intensity on the efficiency of the microfinance institution. The data of financial statements gathered by two leading microfinance institution Planet rating \&microfinance during the period 2002-05 of 100 MFIs were obtained. Efficiency tax which is used as a measure of subsidy intensity. They report that only 5\% of total MfIs are operationally self-sufficient. Their empirical finding by using cross section regression suggest that subsidies have a positive effect on efficiency but upto a certain limit. The effect of the subsidy on efficiency becomes negative above a threshold limit.25\% of the total MFIs are found in this condition. Highlighting the effect of the subsidy on the effectiveness of MFIs is highly policy relevant because MFIs still receives subsidies \& providers of microfinance increasingly demand transparency related to the subsidies on the performance of MFIs.

Qayyum and Ahmed (2006) in their research paper identify most efficient and sustainable MFIs by using DEA in the south Asian region. The study is based on data of 85 MFIs from mix market scattered in the region of Indian, Pakistan \& Bangladesh. The technical efficiency of MFIs is calculated by applying both constant returns to scale \& variable returns to scale.The findings of empirical evidence suggest that eight MFIs from Pakistan, six MFIs from Bangladesh \& five MFIs from India are efficient under variable returns to scale. The combined analysis of three countries disclosed that two efficient MFIs under CRS \& five MFIs are efficient under VRS. Technical natures of inefficiencies arise in three countries. The combined analysis of countries reveals that nineteen MFIs are efficient i.e. eight from Pakistan, six from Bangladesh \& five from India.

Ferdousi (2013) analyses the efficiency of microfinance institution by using DEA in three Asian countries namely India, Pakistan \& Bangladesh. The DEA has been applied under both assumption i.e. constant returns to scale and variable returns to scale. The data of 42 MFIs from china, 89 from India \& 34 MFIs from Bangladesh has been withdrawn from mix market database. Operating expenses \&number of staff have been used as indicator inputs. While gross loan portfolio\& number of active borrowers have been taken as output indicators. Best practice MFIs have been identified by applying DEA. The efficiency determinant also has been identified by using Tobit regression model. The finding of the study revealed that China's \& India's MFIs are efficient or perform better than that of Bangladesh under both assumptions.

Sufian, Majid and Zulkhibri (2007) in their paper investigates the efficiency of finance \& merchant banking institution during the post-consolidation period in Malaysia. By applying DEA methodology on data set 20 finance \& merchant banking institution during the period 2000-2004 following combination of inter mediation approach or assets approach. Total deposit \& fixed assets are used as inputs indicator and total loans and other income is used as output indicators for determination the best practice frontier. The empirical result of the study suggests that pure technical efficiency is more related to overall efficiency than scale efficiency. Only $28.7 \%$ 
institutions are operating at CRS while most of the institutions are inefficient. The result of Tobit regression model suggests that efficiency is positive \& significantly related with market share \& bank capitalisation. Contrary to this, size and economic environment are negatively related with efficiency, overhead expenditure has a positive relationship but insignificant and degree of specialisation \& bank efficiency is positively related to efficiency.

Tahir \&Tahrim (2013) examined \& compared the efficiency levels of five Asian countries namely Indonesia, Philippines, Vietnam, Cambodia \&Laos. Data envelopment analysis with production approach is employed to determine efficiency. This study is based on four-year data for the year 2008 to 2011 withdrew from mix market. Total asset \& operating expenses have been adopted as input while gross loan portfolio \& number of active borrowers are used to measures output. The result depicts that Vietnam has the highest efficiency score (87.6\%) followed by Cambodia (74.6\%) Philippines (65.9\%) \&Loas have the lowest score of (45\%). The pure technical efficiency is lower than the scale of efficiency for Indonesia, Cambodia, Philippines \& Vietnam during the study period.

Wijesiri (2014) examined the technical efficiency of 86 microfinance institutions by applying an innovative two-stage double bootstrap approach. Financial efficiency \& social efficiency is analysed by two different DEA models designed to measure DEA scores. The findings revealed that most of the MFIs are not financially \& socially sustainable. The result of the regression analysis revealed that age \& capital to assets hassignificant impact on financial efficiency. Moreover, age, return on assets and type of the institution have a significant impact on social efficiency.

Nghiem, Coelli\& Rao(2006) analysed the efficiency of microfinance schemes of Vietnam by DEA, SFA and PLP approach. Labour cost and the non-labour cost is used as inputs variables. However, savers, number of borrowers and number of groups are used as output variables. Technical efficiency scores by DEA, SFA \& PLP techniques are $76 \%, 69 \%$ and $78 \%$ respectively. Distance to the township, environmental factors and maturity of scheme significantly affects the efficiency of schemes. Schemes operating in remote area more efficient than others.

Darko (2013) in his research paper determines the efficiency of MFIs by using DEA technique. This study also determined the factors influencing the efficiency of MFIs. The data of 273 Sub-Sahara Africa MFIs is extracted from MIX market database for the period 2005-2011from 35 countries. Overall technical efficiency, scale efficiency and pure technical efficiency has been examined by DEA. The factors influencing OTE \& PTE has been determined with the help of truncated regression model. The findings of the study revealed following production approach personnel expenses, administrative expenses \& financial expenses are used as input indicator. The net loan is used as single output indicator. The findings of the empirical evidence suggest that technical efficiency during the sample period range 0.1003 to 1 , with an average figure of 6288 . Technical efficiency of MFIs is due to managerial efficiency. Scale efficiency is high among commercial MFIs. Overall technical efficiency \& pure technical efficiency is positively related to the age of MFIs \& commercialization of MFIs.

Singh (2014) used an innovative form of the DEA model with input replaced by control factors \& output replaced by performance characteristics. This study is based on data of thirty microfinance institution withdrew from mix market. Equity \& debt \& portfolio at risk are used as control input indicator. While gross loan portfolio, outreach, operating profits and total revenue from gross loan portfolio are used as performance indicator. The result derived from empirical findings revealed that high level of efficiency with an average efficiency score of $63.5 \%$. The control efficiency scores show higher level of efficiency. The study suggests that microfinance institutions has to bear more risk in order to achieve better financial performance \& outreach.

Basharat, Hudon\& Nawaz (2015) used DEA technique to analyze the financial \& social efficiency. Tobit regression model is applied to identify the impact of MFI's social efficiency and financial efficiency. By using data sets of 291 MFIs located in 67 countries for four years (2005-2008) extracted from mix market (global (C) 2019, IJSMS 
database of MFIs). Total assets, operating cost and number of staff is used as input indicators for measuring financial efficiency. Gross loan portfolio and financial revenue are used as output indicator for measuring financial efficiency. Number of women borrowers \& benefit to the poorest is used as output indicators for the measuring social efficiency. The findings of the study revealed that financial efficiency is positively related to the interest rate. Financial efficient MFIs charge lower interest rate. Social efficiency has no relation with interest rate charged by MFIs.

Tahir \& Tahrim (2015) in their research paper employs DEA \& Dynamic Malmquist Productivity Index (MPI) to determine the efficiency of Cambodia microfinance institution during the period 2008-2011. This study applied production approach of DEA on data of thirteen microfinance institution taken mix market. (A Global database of MFIs). Gross loan portfolio \& number of active borrowers are used as output vectors. On the other hand, total assets \& operating expenses are used as inputs vectors. The finding of the study revealed that overall efficiency microfinance of institution in Cambodia slightly has improved $91 \%$ in 2008 \& $92 \%$ in 2009 \& remain stable in $2010 \& 2011$. The technical change had been regularly influencing productivity change during the study period. After decomposing efficiency into technical and scale efficiency change both DEA \& MPI indicates that dominant source of efficiency was scale related rather than technical efficiency.

Kinde (2012) used balanced panel dataset of 14 MFIs over the period 2002-2010 to identify factors affecting financial sustainability of MFIs. Their findings show that breadth of outreach, depth of outreach, dependency ratio and cost per borrower are the significant factors affecting financial sustainability of MFIs in Ethiopia. However, capital structure and staff productivity have an insignificant impact on financial sustainability.

Ali (2013) examined the relationship between financial sustainability and outreach by using data of financial statements and internal records of 30 MFIs that operate in Nairobi (Kenya). He concluded that branches diversification, no. of active borrowers and percentage of female borrowers influenced the financial sustainability of MFIs to greater extent. Average loan size contributes to increased depth of outreach. Moreover, there is strong relationship between financial sustainability and outreach.

\section{MISSION DRIFT: TRADEOFF BETWEEN FINANCIAL PERFORMANCE AND OUTREACH}

The contribution by Mersland\& Strom (2010) examines the mission drift by using panel regression generalised method of movements for average loan \& logistic regression for other depth measures on the data set of 379 MFIs in 74 countries was collected by rating agencies during the years 1998-08. This study investigates about the mission proxy \& lending methodology, main market $\&$ genders bias as further mission drift measures. Their empirical finding did not find any evidence of mission drift . The econometric evidence supports that average loan size increase with increase in average profits $\&$ average operational costs.

Gakhar (2013) in his empirical study of MFIs in Indian economy study the outreach and financial performance. This study analyses the data of 40 microfinance institutions taken from mix database for the period 2004 to 2011. The mix is a global database that provides data of that provide data of 1400 MFIs around the globe. The regression analysis model is used to identify a trade-off between outreach \&financial performance. The empirical evidence suggests data increased the level of outreach improves financial performance . They conclude that MFIs can achieve dual objective of outreach \& financial performance.

Kaur (2014) in her study titled "outreach \& sustainability of MFIs in India in pre \&post-Andhra Pradesh microfinance crisis in the context of south Asia highlighted various dimensions of sustainability \& outreach of MFIs in south Asia. The study analysis the data for the year 2008 to 2011 of south Asian MFIs. Their finding suggests that OSS of MFIs is better than MFIs in Afghanistan \& Pakistan. After Andhra crisis, cost per borrower has increased \& it is lowest in India. Portfolio quality of Indian MFIs has also improved after the crisis. 
Gashayie and Singh(2014) investigate the association between financial sustainability and outreach of Ethiopian MFIs by using data of 5 MFIs for the year 2011. Number of borrowers and average loan size adjusted by GNP per capita as proxies for measuring outreach. Their findings revealed that there is no significant relationship between outreach and financial sustainability.

Louis et. al. (2013) in their study used innovative methodology by using self-organising map methodology. This methodology is used to study existing heterogeneity among institutions. This study investigates the trade-off between social efficiency \& financial performance by using data sets of 650 microfinance institutions withdraw from the mix market i.e. (A Global database of MFIs). The study uses three indicators of outreach such as depth of outreach to women \& average loan size/GNI per capita. The real yield on gross portfolio \& profit margin is used as profitability indicators \& gross loan portfolio to asset \& cost per loan is used as efficiency variable. The portion of women borrower is used as continuous variable. The findings of the study reveal that there is no trade-off between social performance \& financial performance. The evidence of empirical research depicts the positive relationship between social \& financial performance.

Kapisha and Zhang (2013) examine the tradeoffs between sustainability, profitability and outreach to poor by using unbalanced panel data sets of 47 MFIs for the period 2008 to 2011 in east Africa. Average loan balance per borrower adjusted by GNI per capita, the number of active borrowers and percentage of women borrowers are used as proxies for measuring outreach. Operational self-sufficiency ratio is a proxy for sustainability. Return on assets as a proxy for Profitability. Their findings confirm tradeoffs between outreach to poor with profitability and absences of tradeoffs with sustainability measures. They suggest that MFIs can focus on sustainability to enable those covering operating costs with less dependence on subsidies without compromising outreach to poor.

Hermes $\boldsymbol{e t}$. al. (2011) in their empirical evidence, "outreach \& efficiency of microfinance institution" found convincing evidence that outreach is negatively related to the efficiency of microfinance institutions. The large data sets of 435 institutions for the period of 1997-2007 were used to determine the relationship between cost efficiency of MFIs \& the depth of outreach measured on the basis of average loan balance \& percentage of women borrowers. They applied SFA (stochastic frontier analysis) model to calculate the cost efficiency of microfinance institution \& then correlation analysis to determine the trade-off between outreach \& efficiency .Their finding suggests that MFIs that have more women borrowers \& lower average balance are also less efficient .The findings of the correlation between measures of efficiency \& outreach show that outreach is negatively related to the efficiency of MFIs.

Quayes (2012) in his paper investigate the dynamic relationship between the depth of outreach \& financial sustainability. The data of seven hundred three MFIs from eighty-three countries for the year 2006 were taken from mix (microfinance information exchange). The average loan size /GNI, the percentage of women borrowers is used as outreach indicator. Gross loan portfolio, total equity, debt to equity, total expense ratio, cost per borrower, and dummy variable of operational self-sufficiency is used as financial efficiency variable. Ordinary least square \& regression analysis is applied to investigate the relationship between financial efficiency \& outreach. They did not find any evidence of trade off except for low disclosure MFIs.

Wydicket. al. (2011) investigated about the nature of the influence that social network has on credit access \& factors affecting outreach. This paper uses new approach in determining the role of social networks in determining credit access. He conducted survey of 465 households in western Guatemala for gathering information on education, ownership of different assets, membership in churches \& participation in village committee. Information was gathered by asking question from the related to purchasers of new consumer goods such as bicycles, television cell phones \& information source for accessing credit. With the help of regression equation effects of social networks at the neighbourhood, church \& village levels for borrowing credit is estimated. The empirical finding of the study suggested the presence of endogenous peer effect for borrowing credit are similar to those found in the purchase \& ownership of consumer goods of bicycles, cell phones \& 
television. They find that the effect of social groups is significant in credit access. They also find that microfinance borrowing is positively related with the level of education but negatively related to wealth level of social network household's village \& church.

Serrano-Cinca\& Gutiérrez-Nieto(2014) identified the microfinance mission following the Pareto's 80/20 principle. The empirical findings of the study are based on data set of 1000 microfinance institution from the MIX market for the year 2006 to 2010. The datasets of 1000 microfinance institutions have been categorised into two groups i.e. (the most centered MFIs \& the most drifted MFIs). The most drifted MFIs indicate failure of the social mission of microfinance. The findings of the study reveal that some MFIs have drifted from their social mission. This study is highly relevant for donors, social investors \& rating agencies. The findings of the study suggest that there is a need to reduce the interest rate. This can be done by using efficient technology as in other sectors.

Quayes (2012) presented first empirical evidence of positive relationship between the depth of outreach \& financial self-sufficiency by using large data sets of 702 MFIs operating in 73 countries. Based on the quality of information provided by MFIs to mix market. MFIs have categorized into two group i.e. low disclosure MFIs \& high discloser MFIs. The finding of the study revealed that financial sustainability has no impact on outreach. The result on the basis of disclosure level revealed tradeoff for the low disclosure MFIs. However, high disclosures MFIs have positive relationship between outreach \& financial sustainability. The depth of outreach increases financial sustainability for high disclosure MFIs. Low disclosure MFIs depth of outreach has no impact on financial sustainability.

Hermes and lensik (2007) provided large-scale systematic analysis of contributions revealed to the tradeoff between outreach and sustainability of microfinance institution. Their findings revealed that individual based MFIs focus more on the wealthier client in comparison to group based lenders.

Copestake (2007) analyzed mission drift by an innovative model that differentiates between financial and social performance possibilities, preferences and assessment system. The model is used to illustrate the relationship between social and financial performance and to give suggestion for policy analysis. The conceptual framework developed in this paper that distinguish between financial and social performance possibilities can be applied to determine how other financial institutions contribute to economic growth and equity goal.

The author (Cull et. al., 2011) presented first empirical contribution revealed to the effect of regulation on MFIs profitability and outreach. This issue is answered by using the high quality balance sheet and income statements for 245 leading MFIs with supervision data of each MFIs. The findings of regression analysis revealed that profit oriented MFIs respond to supervision by maintaining profit rates but reducing outreach to women and core poor that are costly to reach.

Zeller and Meyer (2002) in their book bring together empirical research work done by IFRI researches and other collaborating institutions. For the microfinance practitioners, it provides judicious decisions of tradeoffs \& what role finance can play in achieving long-term poverty alleviation and economic growth.

The author (Hermes and Lensink, 2011) provided detailed analysis of eight empirical contributions related to the two main question (i) does microfinance have an impact on the social and economic situation of the poor in developing countries (ii) are microfinance institution sustainable in the long terms and there is tradeoff between sustainability and outreach to poor. In-depth study of the reviewed symposium revealed that there is strong tradeoff between the outreach and sustainability (Hermes et. al. 2011) similarly transforming MFIs into banks does not have any positive consequences for the poor (Cull et. al. 2011). The symposium of Hudon and Traca (2011) conclude that subsidies do not compromise with the efficiency of MFIs as long as subsidy level remains moderate. This paper supports the view that financial sustainability is not only necessary when aiming the long term viability of microfinance. The findings of (Wydicket. al., 2011) symposium revealed that use of existing social network between existing and potentially new client increased outreach to poor and reduce costs of 
reaching outreach to poor and reduced cost of reaching out. The size of trade off i.e. improving the financial sustainability of an MFI mean in terms reducing outreach to the poor client is first studied by Galema and Lensink (2009). Their result suggests that trade-off is particularly severe for group that is typically targeted by MFIs.

Mersland\& Storm (2008) examined the impact of the type of ownership on Microfinance organization performance. This study considers six aspects of performance dimensions namely cost, depth, breath, length, scope and worth. Multivariate logit regression is used to predict the organizational type of either NGO or shareholder fund. The empirical evidence is based on database of 200 nongovernmental or shareholder MFOs representing 54 countries. The findings of the study revealed that difference is minimum between SHFs and NGOs in terms of social and financial performance.

\section{LOAN REPAYMENT PERFORMANCE}

Bassem (2013) examined the relationship between MFIs governance and repayment performance. The empirical investigation is based on data of 250 MFIs from Mix market database from different countries. The portfolio at risk 30 days is used as a dependent variable and proxy for loan repayment performance and other firm-specific variables as independent variables. The results indicate that MFI's size and use of individual level model improve the loan repayment performance. However, the MFIs age positively affects the percentage of portfolio at risk.

Aseefa, Hermes and Meesters (2010) examined the effect of competition among MFIs on their performance. They used innovative approach by constructing Lerner index, they assessed the effect of increase competition on outreach, loan repayment performance and financial performance. The empirical investigation is based on datasets of 362 MFIs taken from MIX market database over the period 1995-2009. They concluded that competition is negatively associated with outreach while it is positively associated with rising defaults. Increased competition is negatively associated with efficiency of MFIs.

Mosbah, Slama and Mostorakis in their paper identified determinants of loan repayment default phenomenon. Data of 30 MFIs is withdrawn from MIX (Microfinance information exchange) market database in MENA region. Their regression findings revealed that average loan balance per borrower and gross loan portfolio positively affects the portfolio at risk. Moreover, empirical findings confirm that higher percentage of female clients is associated with lower portfolio at risk.

Crabb\& Keller (2006) in their empirical work used data of 37 MFIs studied over 12 quarters of individual trust bank and group lending model located in different countries. To determine how lending methodology contributes to loan repayment performance measured by using portfolio at risk 30 days. Their findings revealed that group lending methodologies reduce the risk in MFIs portfolios compared to individual loans. However, greater lending to women raises portfolio at risk.

\section{CONCLUSION}

The literature has been reviewed related to research issues covered in this study such as financial selfsufficiency, operational self-sufficiency, portfolio at risk and trade-off between financial self-sufficiency and outreach to female clients and poor.

\section{REFERENCES}

[1] Ahmad, U. (2011). Efficiency Analysis of Micro-finance Institutions in Pakistan.

[2] ALI, K. H. (2013).The relationship between financial sustainability and outreach of microfinance institutions in Kenya.(Unpublished master's thesis).University of Nairobi, Nairobi.

[3] Assefa, E., Hermes, N., \&Meesters, A. (2013).Competition and the performance of microfinance institutions. Applied Financial Economics,23(9), 767-782. 
[4] Basharat, B., Hudon, M., \& Nawaz, A. (2015). Does efficiency lead to lower prices? A new perspective from microfinance interest rates. Strategic Change, 24(1), 49-66.

[5] Bassem, B. S. (2013). Governance quality and mfis repayment performance. journal of economic cooperation \& development, 34(2), 47.

[6] Copestake, J. (2007). Mainstreaming microfinance: social performance management or mission drift? World Development, 35(10), 1721-1738.

[7] Crabb, P. R., \& Keller, T. (2006).A test of portfolio risk in microfinance institutions. Faith \& economics, 47(48), $25-39$.

[8] Cull, R., Demirgüç-Kunt, A. \& Morduch, J. (2011). Does regulatory supervision curtail microfinance profitability and outreach?.World Development, 39(6), 949-965.

[9] Darko F.A. (2013). Commercialisation and efficiency of microfinance institutions in Sub-Saharan Africa.Retrieved fromhttps://www.uea.ac.uk/.../7ce2ef6f-7381-458d-b51a-e9331c1b7bf7

[10] De Crombrugghe, A., Tenikue, M., \&Sureda, J. (2008).Performance analysis for a sample of microfinance institutions in India. Annals of Public and Cooperative Economics, 79(2), 269-299.

[11] Ferdousi, F. (2013, December).The performance of Microfinance Institutions in Asia: DEA based Efficiency Analysis. In 2013 International Conference on the Modern Development of Humanities and Social Science.Atlantis Press.

[12] Gakhar, K. (2013). Financial performance and outreach of microfinance institutions: is there a trade-off?-an anempirical study of Indian economy. Global Management Review, 7(4).

[13] Gashayie, A. \& Singh, M. (2014).Relationship of financial Sustainability and Outreach in Ethiopian

[14] Gutierrez-Nieto, B., Serrano-Cinca, C., \&Molinero, C. M. (2007).Microfinance institutions and efficiency. Omega, 35(2), 131-142.

[15] Gutiérrez-Nieto, B., Serrano-Cinca, C., \&Molinero, C. M. (2009).Social efficiency in microfinance institutions. Journal of the Operational Research Society, 104-119.

[16] Hassan, K. M., \& Sanchez, B. (2009).Efficiency analysis of microfinance institutions in developing countries. Networks Financial Institute Working Paper.

[17] Hermes, N., \&Lensink, R. (2007). The empirics of microfinance: what do we know? The Economic Journal, 117(517), F1-F10.

[18] Hermes, N., \&Lensink, R. (2011). Microfinance: its impact, outreach, and sustainability. World Development, 39(6), 875-881.

[19] Hermes, N., Lensink, R., \&Meesters, A. (2011).Outreach and efficiency of microfinance institutions. World Development, 39(6), 938948.

[20] Hudon, M., \&Traca, D. (2011). On the efficiency effects of subsidies in microfinance: An empirical inquiry. World development, 39(6), 966-973.

[21] Kaur, P. (2014). Outreach and Sustainability of Microfinance Institutions in India in Pre and Post Andhra Pradesh Microfinance Crisis in Context of South Asia. Global Journal of Finance and Management, 6(6), 569-574.

[22] Kinde, B. A. (2012). Financial sustainability of microfinance institutions (mfis) in Ethiopia. European journal of Business and Management, 4(15), 1-10.

[23] Kipesha, F. E., \& Zhang, X. (2013). Sustainability, Profitability and Outreach Tradeoffs: Evidences from Microfinance Institutions in East Africa. European Journal of Business and Management, 5(8).

[24] Martinez-Gonzalez, A. (2008). Technical efficiency of microfinance institutions: Evidence from Mexico (Doctoral dissertation, The Ohio State University).

[25] Masood, T., \& Ahmad, M. (2010). Technical Efficiency of Microfinance Institutions in India-A Stochastic Frontier Approach.MPRA, 25454.Retrieved from http://mpra.ub.uni-muenchen.de/25454/.

[26] Mersland, R., \&Strøm, R. Ø. (2008). Performance and trade-offs in Microfinance Organisations-Does ownership matter? Journal of International Development, 20(5), 598-612.

[27] Mersland, R., \&Strøm, R. Ø. (2010).Microfinance mission drift? World Development, 38(1), 28-36.

[28] Microfinance Institutions: Empirical Evidence. Research Journal of Accounting and Finance, 5(17).

[29] Mosbah, E., Slama, M. M. B., \&Mastorakis, N. Micro Finance Institutions' behaviour: Determinants of portfolio quality in MENA region.Recent Advances on Finance Science and Management, 68-71. Retrieved from www.wseas.us/elibrary/conferences/2015/Seoul/MF/MF-10.pdf. 
[30] Nawaz, A., Hudon, M., \&Basharat, B. (2011). Does efficiency lead to lower interest rates? A new perspective from microfinance. In Second European Research Conference in Microfinance, Groningen, The Netherlands.

[31] Nghiem, H., Coelli, T., \& Rao, D. S. P. (2006). The efficiency of microfinance in Vietnam: Evidence from NGO schemes in the north and the central regions. International Journal of Environmental, Cultural, Economic and Social Sustainability, 2(5), 71-78.

[32] Qayyum, A., \& Ahmad, M. (2006).Efficiency and Sustainability of Micro Finance Institutions in South Asia. South Asian Network of Economic Research Institutes (SANEI).

[33] Quayes, S. (2012). Depth of outreach and financial sustainability of microfinance institutions. Applied Economics, 44(26), $3421-3433$.

[34] Quayes, S. (2012). Depth of outreach and financial sustainability of microfinance institutions. Applied Economics, 44(26), $3421-3433$.

[35] Rai, A. K. (2012). A comparative analysis of the financial performance of microfinance institutions of India and Bangladesh.(Unpublished Doctoral dissertation, Jaypee institute of Information Technology).

[36] Schafer, K. \&Fukasawa, Y. (2011).Factors Determining the Operational Self-Sufficiency among Microfinance Institutions. Advances in Business Research, 2(1), 171-178.

[37] Serrano-Cinca, C., \& Gutiérrez-Nieto, B. (2014). Microfinance, the long tail and mission drift. International Business Review, 23(1), 181-194.

[38] Singh.T.R. (2014).A Study of the Efficiency of Micro Finance Institutions Using Data Envelopment Analysis.Indian Journal of Applied Research, 4(11).

[39] Sufian, F., Majid, M. Z. A., \&Zulkhibri, M. (2007). Consolidation and efficiency: Evidence from non-bank financial institutions in Malaysia (No. 12128). University Library of Munich, Germany.

[40] Tahir, I. M., \&Tahrim, S. N. C. (2015). Efficiency and Productivity analysis of microfinance institutions in Cambodia: A DEA approach. International Review of Business Research Papers, 11(1).

[41] Tahir, I.M. \&Tahrim, S.N.C. (2013), Efficiency Analysis of Microfinance Institutions in ASEAN: A DEA Approach. Business and Management Dynamics, 3(4), 13-23.

[42] Tehulu, T. A. (2013). Determinants of financial sustainability of microfinance institutions in East Africa. European Journal of Business and Management, 5(17), 152-158.

[43] Wijesiri, M. (2014). Essays in efficiency and productivity analysis of microfinance institutions (Doctoral dissertation, University of Bergamo).

[44] Wydick, B., Hayes, H. K., \&Kempf, S. H. (2011). Social networks, Neighborhood effects, and credit access:evidence from rural Guatemala.World Development, 39(6), 974-982.

[45] Yaron, J. (1994). Successful rural finance institutions. Finance and Development, 31(1), 32.

[46] Zeller, M., \& Meyer, R. L. (Eds.). (2002). The triangle of microfinance: Financial sustainability, outreach, and impact. Intl Food Policy Res Inst.

[47] Zerai, B. \& Rani, L. (2012). Technical Efficiency and its Determinants of Micro Finance Institutions in Ethiopia: A Stochastic Frontier Approach. African Journal of Accounting, Economics, Finance and Banking Research, 8(8), 1. 